\title{
Anatomical and Palynological Features of Heliotropium supinum L.
}

\author{
AL-Hadeethi, Muazaz A., Al-Anbari, Aseel K. and Ali T. Mohammed
}

\begin{abstract}
In this study a compare between the morphological and anatomical structure parts of the species Heliotropium supinum in Turkey specifically from Pamukkale were carried out to diagnostic the characters of it, this will helping to identify parts of this species. It had been found that the species reached to $0.55 \mathrm{~m}$ in height, the stem cylindrical, hairy and fleshy and the inflorescences are hilioscopia and the flower convolution in double rows also the cross section of stem appear that the shape of stem oval and the epidermis surface is wavy and covered by trichomes, cortex consists from 4-6 layered of collenchyma beneath the epidermis and 7-11 layered of parenchyma also can discrimination ten specialized schizogenous intercellular space in the cortex that store the active compounds, phloem element and xylem are noted and the pith at the center with abounded resin ducts.

The transverse sections of the leaves showed that the upper and lower epidermis is single layer irregular in shape with sinuous and thick walls covering by unicellular and uniseriate trichomes, follow the epidermis two palisade layers, under it three spongy layers, midrib of leaf consists of a single layer of epidermis covering by unicellular and uniseriate trichomes and collenchyma layer beneath the epidermis so the parenchyma tissues is full up the inside of midrib, vascular bundle open and collateral, crescent shaped, consists of xylem and phloem. The petiole of leaf drumstick or bone shape, the epidermal cells 4-5, wavy on the adaxial and abaxial side and covering by trichomes, stomata are on the adaxial and abaxial surface, anisocytic type. The scanning study of mature pollen grains of Heliotropium supinum showed that the pollen small size, prolatespheroidal shape, monoporate and the exine sculpturing psilate.
\end{abstract}

Keywords-Heliotropium supinum, Boraginaceae anatomy, palynology, morphology.

\section{INTRODUCTION}

$\mathrm{H}$ eliotropium supinum L. is a perennial herb, commonly known as heliotrope, seaside heliotrope or salt heliotrope because grow in the salty soil, sand and alkali soils, therefore considered from the halophytes plant also known kīpūkai in Hawaii (Anonymous, 2003 ).

The species is native to the America, Canada, and Argentina and distributed in different countries as a common species in it like as Turkey and Iraq (Sergeev, 2009).

Muazaz Azeez Hasan is with the Department of Biology, College of education for pure sciences ( Ibn- Al- haitham), Baghdad University, IRAQ *Corresponding Author

Aseel Kadhim and Hadi Al-Anbari is with the Department of Biology, College of education for pure sciences, Diyala University, IRAQ

Ali Talib Mohammed is with the Continuous Learning Center, Mustansiriyah University, IRAQ.
Halophytes are adapted to bear severe salinity and dry conditions by synthesizing a number of chemicals to maximize their suitability for the environment, for this reason, many sources of herbal medicine against a number of chronic diseases (Allen, 1982).

Heliotropium supinum parts are used as a drug in herbal medicine like as the young leaves and stem used to treat the ulcer of throat and dysmenorrhea in India also to be used for head's pain, chest, and pain in the leg in Canada (Anon, 1962).

Chemically, Heliotropium supinum contains many compounds like as Alkaloids, Flavonoids, Phenols, Amino acids and Saponins (Rastogi and Mehrotra, 1989 and (Satyavani et al., 2013).

Earlier studies on Heliotropium supinum study the Physiological and chemical compounds like as studied of (Gokulnath, et al., 2014, Hussein, et al., 2013 and Subramanian, et al., 2013). Hence, very few studies refer to the anatomical parts of this plant. Therefore, the objective of this study is to clarify the anatomical parts of cross sections of stem, leaves, petioles, and epidermis of the leaf with an appendix, in addition, study the pollen grains by light microscope (LM) and scanning electronic microscope (SEM) as a new study to this species in Iraq.

\section{MATERIAL AND METHODS}

\section{A. Collect the plants:}

Fresh material of Heliotropium supinum was collected through tours in Antalya of Turkey specifically from Pamukkale.

\section{B. Prepare the epidermis:}

The epidermis prepared to follow by (Foster, 1977). We're clearing with distilled water, put it in $10 \% \mathrm{KOH}$, then put in ethanol alcohol for 9-12 min and stained by $1 \%$ safranin for 30-45 min. Finally, the samples were put on the slides with Dextrin Plasticizer Xylene (D.P.X) and covered by cover slides.

Prepare the sectioning parts of stem, petiole and leaf:

Fresh material of stem, leaves and petioles was fixed in formalin acetic acid (FAA) at 24 hours and changed the solution to put samples in the ethanol (70\%). Samples were put in paraffin wax then sectioned by a rotary microtome and stained with safranin and fast green stain and then mounted with Dextrin Plasticizer Xylene (D.P.X). The prestaining and staining procedure was performed according to 
(Thammathaworn, 1996).

To find the stomatal index follows (Stace, 1965) as:

Stomatal index $=$ (number of stomata $) /($ number of stomata + number of ordinary epidermal cells $) \times 100$

All permanent slides were examined by KRÜSS light microscope and photographed using AmScopoe camera.

\section{Prepare the pollen grains:}

Pollen sample of Heliotropium supinum was prepared using the acetolysis method as described by Erdtman (1960). The measurements and observations were carried out using both light microscope (LM) and scanning electron microscope (SEM).

For LM analysis, the acetolysed pollens were put in a vial with 5-7 drops of silicone oil and then the samples were mounted on a glass slide and observed under light microscope. The measurements of polar axis $(\mathrm{P})$, equatorial diameter $(\mathrm{E})$ and exine thickness of pollen were done using 15 reading samples for each specimen.

For SEM investigation, the acetolysed pollen was put in $100 \%$ ethanol, then was put on an aluminum stub, coated with gold and observed using LEO 1450VP Electron Microscopy. The terminology and pollen size classes follow (Walker and Doyle, 1975).

\section{RESUlt AND DisSECTION}

\section{A. Characters of general shape}

The plant reached to $0.55 \mathrm{~m}$ in height, the stem cylindrical, hairy and fleshy, leaves are hairy, simple, petiolet, dark green and ovate in shape. The inflorescences are hilioscopia and the white flower convolution in double rows, small and bellshaped, calyx contains 5 dentate sepals, and corolla contains 5 ovule petals with a purple or yellow ring inside the lobes. The fruit consists of 4 nutlet and the results are consistent with (Huber Morath, 1978) (Figure 1).

\section{B. Cross section of stem}

The stem oval shape, thickness up to 2.3-5.5 $\mathrm{mm}$, the surface is wavy and covered by trichomes. The epidermis is single layered polygonal to spherical cells, cortex consists of 4-6 layered of collenchyma beneath the epidermis and 7-11 layers of parenchyma also can discrimination ten specialized schizogenous intercellular space in the cortex that store the active compounds. The vascular tissue is a continuous ring consists from xylem in radial rows and the phloem is outside the xylem. The pith at the center with abounded resin ducts and the results are confirm with (Banerji, 1962).

\section{Cross section of leaf}

Blade of leaf covering by unicellular and uniseriate trichomes from the upper and lower side, the thickness of it reached to 233-289 $\mu \mathrm{m}$ (263.5). Upper epidermis is single layer contain from large cells irregular in shape with sinuous and thick walls, 30-55 (40) $\mu \mathrm{m}$ in thickness, follow the epidermis two palisade layers, 153.75-158.5 (156.5) $\mu \mathrm{m}$ in thickness, under it three spongy layers the thickness of it reached to $125-140(132.5) \mu \mathrm{m}$ and the lower epidermis like as the upper the thickness of it 32-54 (43) $\mu \mathrm{m}$.

The midrib of leaf consists of a single layer of epidermis covering by unicellular and uniseriate trichomes, collenchyma layer beneath the epidermis and parenchyma tissues is full up the inside of midrib.

Vascular bundle, open and collateral, 85-130 $\mu \mathrm{m}$ (122.5) in thickness, crescent shaped, consists of xylem and phloem.

All the result agrees with Hoyam and Maha (2012).

\section{Cross section of petiole}

The petiole drumstick or bone shape, the surface is wavy and covered by unicellular and uniseriate of trichomes. The epidermis is single layered polygonal to spherical cells, Cortex consists from 2-4 layered of collenchyma beneath the epidermis and 4-5 layered of parenchyma. The vascular tissue is a continuous take the form of the section consists from xylem in radial rows and the phloem is outside the xylem covered from outside by sclerenchyma cells distributed as groups. The pith at the center with abounded resin ducts and the result agree with a study of Evenari (1938).

\section{E. Epidermis of leaf}

Epidermal cells 4-5, wavy on the adaxial and abaxial side. Trichomes are unicellular and uniseriate conical in shape, distributed in all the parts of the plant. Stomata are on the adaxial and abaxial surface, anisocytic type, stomatal frequency $82 / \mathrm{mm} 2$ on the adaxial side and $81.5 / \mathrm{mm} 2$ in the abaxial side, stomatal index 3.09 on the adaxial side and 3.11 in the abaxial side, stomata length $25-30$ ( 28.5 ) $\mu \mathrm{m}$ and width 20-25 ( 23.3 ) on the adaxial side in diameter, stomata length 33-41 ( 36.3 ) $\mu \mathrm{m}$ and width 25.8-34.1 ( 29.9 ) on the adaxial side and that confirm the results of (Hoyam and Maha, 2012).

\section{F. Pollen grain}

The results of the pollen morphology of Heliotropium supinum are summarized in Table 1 The mature pollen grains small size, prolate-spheroidal shape, monoporate and the exine sculpturing psilate. 
TABLE. I: The Results Of The Pollen MoRPhOlogy OF HeLIOTROPIUM SUPINUM

\begin{tabular}{|c|c|c|c|c|c|c|c|}
\hline Species & $\begin{array}{c}\text { Polar axis }(\mu \mathrm{m}) \\
(\mathrm{Mean} \pm \mathrm{SD})\end{array}$ & $\begin{array}{c}\text { Equatorial axis } \\
(\mu \mathrm{m}) \\
(\mathrm{Mean} \pm \mathrm{SD})\end{array}$ & $\begin{array}{c}\mathrm{P} / \mathrm{E} \\
\text { Ratio }\end{array}$ & Shape & Size & $\begin{array}{c}\text { Exine } \\
\text { sculpturing } \\
(\mu \mathrm{m}) \\
(\mathrm{Mean} \pm \mathrm{SD})\end{array}$ \\
\hline Heliotropium supinum & $\begin{array}{c}16.5-20.5 \\
(17.54 \pm 1.39)\end{array}$ & $\begin{array}{c}15.5-21.0 \\
(17.39 \pm 1.65)\end{array}$ & 1.01 & $\begin{array}{c}\text { Prolate } \\
\text { spheroidal }\end{array}$ & small & $\begin{array}{c}0.87-1.05 \\
(0.93 \pm 0.10)\end{array}$ & psilate \\
\hline
\end{tabular}

\section{REFERENCES}

[1] Anonymous, A. 2003. Check list of Homoeopathic Medicinal Plants of India, Revised ed. In: D. Suresh Baburaj, editor. Central Council for Research in Homoeopathy. Ministry of Health and Family Welfare. New Delhi: Govt. of India; p. 34.

[2] Sergeev A. 2009. Flora of Qatar. pp:1-89.

[3] Allen TF. 1982. The encyclopedia of pure meteria medica. Repr. Ed, Vol. 4. New Delhi, India: B. Jain Publishers; p. 546.

[4] Anon A. 1962. Wealth of India, raw materials. Vol. 6. New Delhi: Publications and Information Directorate, CSIR; p. 346.

[5] Rastogi RP and Mehrotra BN. 1989. Compendium of Indian Medicinal Plants, Vol. 1- 4. New Delhi: CDRI., Publication and Information Directorate; 1960 -.

[6] Satyavani KS. Gurudeeban VD and Ramanathan T. 2013. Heliotropium supinum mediated Silver Nanoparticles for Environmental Application Res. J. Chem. Environ. 17(3): 27-33.

[7] Gokulnath M.; Yuvaraj D.; Gayathri PK.; Chandran M.; Vivek P. and Kesavan D. 2014. Phytochemical Screening And Anti-Bacterial Studies In Salt Marsh Plant Extracts (Spinifex littoreus (BURM.F) MERR. and Heliotropium supinum L.). International Journal of ChemTech Research. 6(9):4307-4311.

[8] Subramanian P.; Padma P.; Sudhakar P., Sheshashena TP. and Reddy R. (2013). Pharmacognostic evaluation of Heliotropium peruvianum L.: A homoeopathic drug. Indian Journal of Research in Homoeopathy. 7(3) 103-108.

https://doi.org/10.4103/0974-7168.119109
[9] Hussein FF.; Abdallah MS. and Tha'ar FM. 2013. To compare the allelopathic potentiality of two Heliotropium species on the growth of Calotropis procera and Lycopersicon esculentum. International Research Journal of Plant Science 4(8): 222-235.

[10] Huber Morath A. 1978. Heliotropium L. Flora of Turkey and the East Aegean Islands. Edinburgh University Press, Vol. 6, pp: 461-600.

[11] Foster WD. 1977. Freehand sectioning of bryophytes. Bull. Brit. Bryol. Soc. 29: 21.

[12] Stace CA. 1965. The signification of the leaf epidermis in the taxonomy of the combretaceae. general Review of Tribal Genera and Specific Characters. J. Linn. Soc. (Bot.), 59: 229-252. https://doi.org/10.1111/j.1095-8339.1965.tb00060.x

[13] Thammathaworn A. 1996. Handbook by paraffin method. Department of biology, Faculty of science, Khon Kaen Universality, Thailand.

[14] Erdtman G. 1960. The Acetolysis Method (A revised description). Svensk Botanisk Tidskrift, 54(4):561-564.

[15] Walker JW. and Doyle, JA. 1976. The basis of Angiosperm phylogeny: Palynology. Ann. Mo. Bot. Gard., 62: 666-723.

[16] Hoyam OA. and Maha AK. 2012. Leaf and Stem Anatomy of five species from the genus Heliotropium L. (Boraginaceae) in Sudan, Journal of Chemical and Pharmaceutical Research, 4(10):4575-4581.

[17] Banerji FNI. 1962. Compative studies in four species of Hiliotropium. University of Calcutta, 29 (1) 1-40.

[18] Evenari M. 1938. Anatomy of the Genus Heliotropium. Pergmon press. New York,
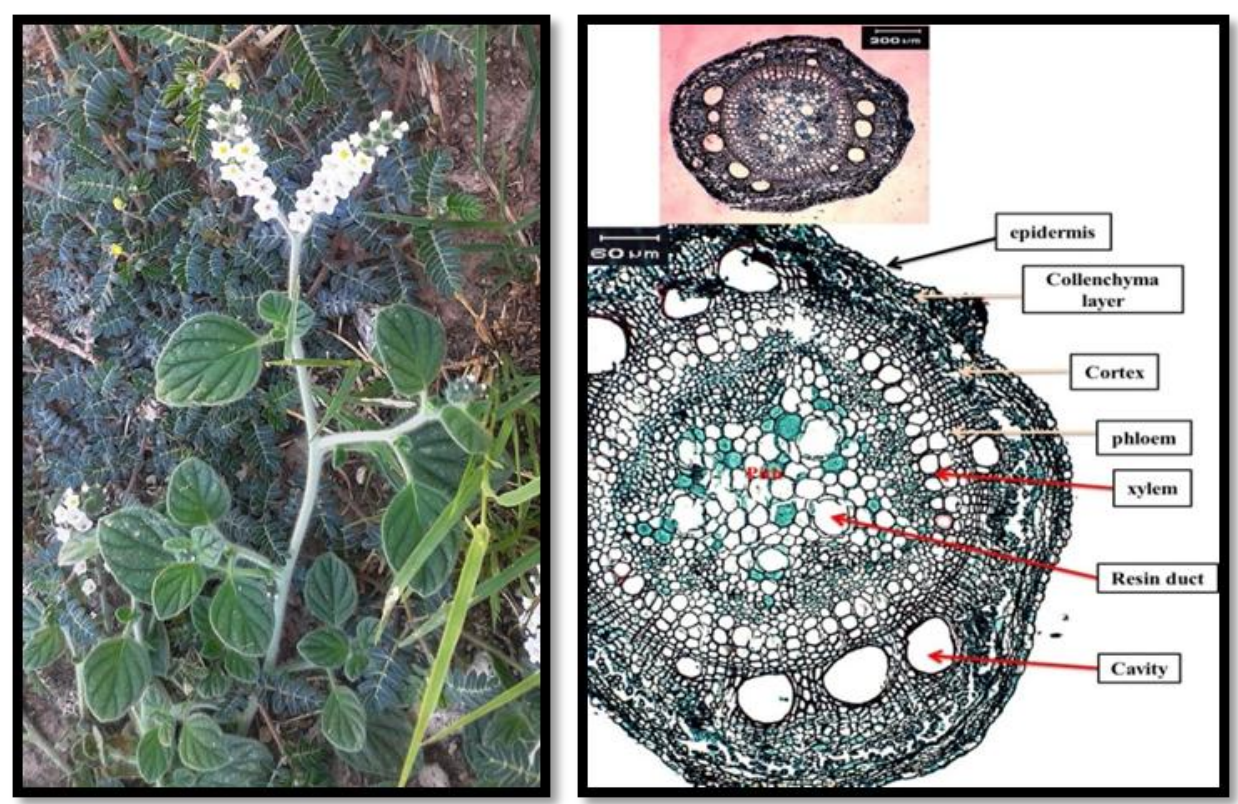

Fig. 1: Heliotropium supinum

Fig. 2: Cross section of Heliotropium supinum stem 


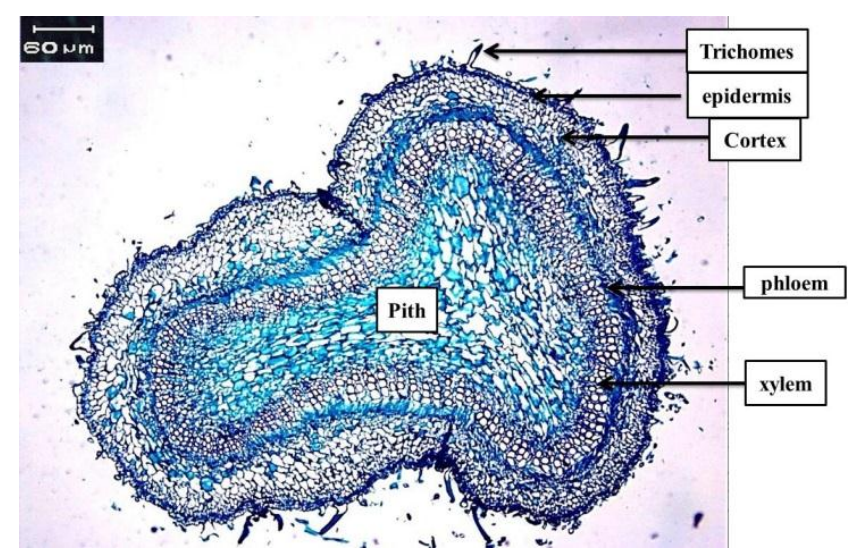

Fig. 3: Cross section of Heliotropium supinum petiole.

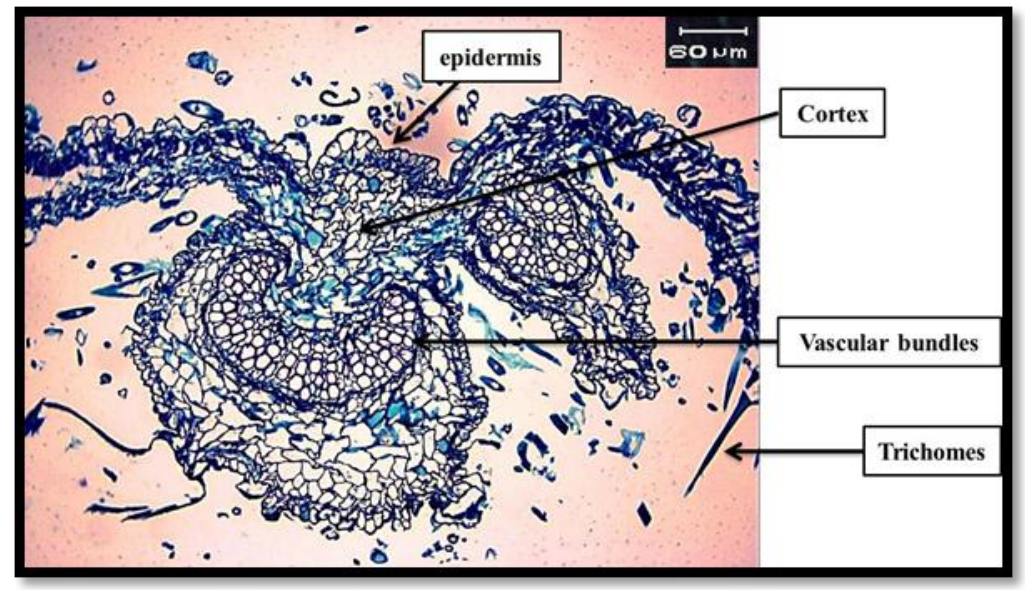

Fig. 4: Cross section of Heliotropium supinum midrib.

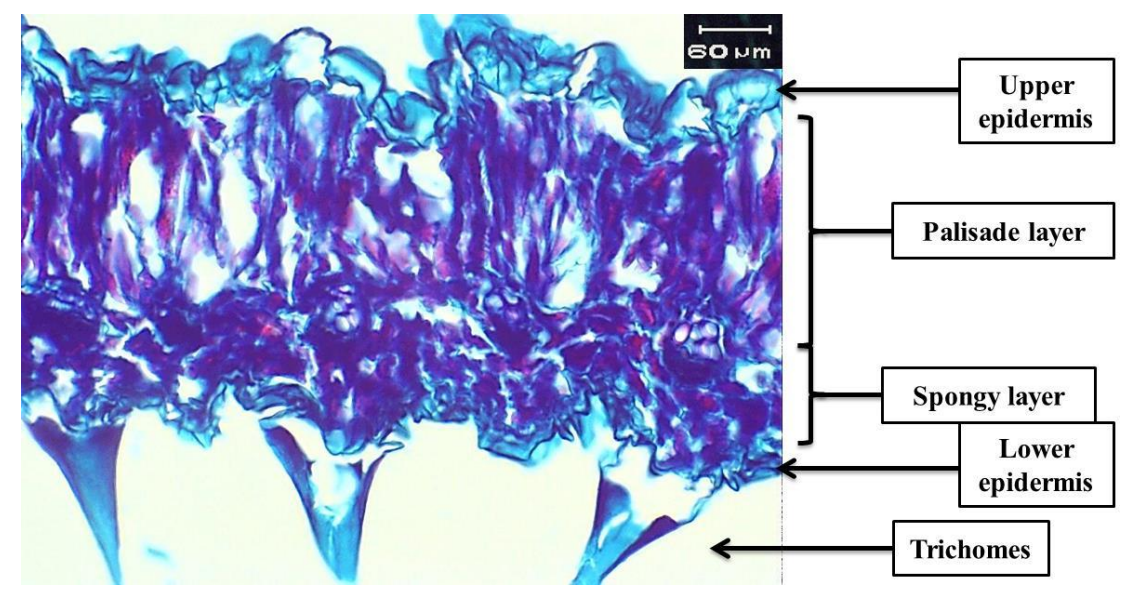

Fig. 5: Cross section of Heliotropium supinum blade 

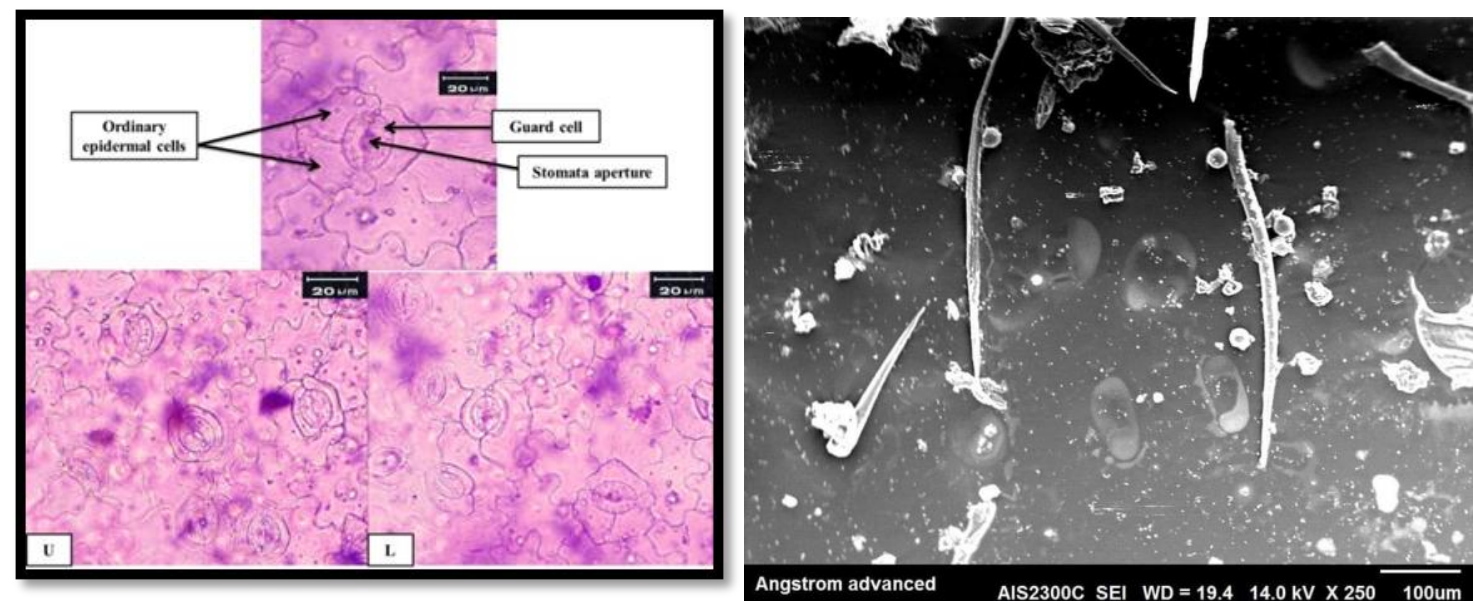

Fig. 6: Stomata of Heliotropium supinum.

Fig. 7: Pollen grain and trichomes in Heliotropium supinum by SEM.

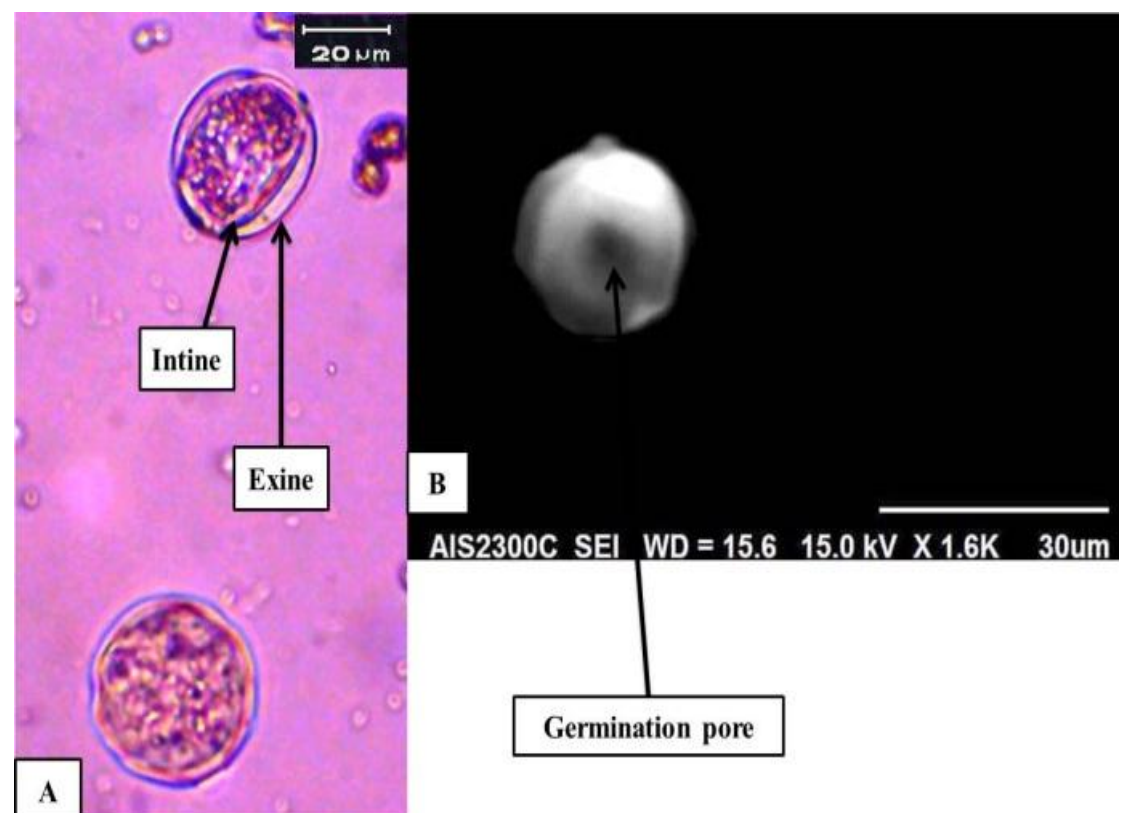

Fig. 8: Shape of pollen grain in Heliotropium supinum, A: by LEM and B: by SEM. 